\title{
The Chronic Kidney Disease Epidemic in El Salvador: A Cross-Sectional Study
}

\author{
Carlos Manuel Orantes-Navarro MD, Miguel M. Almaguer-López MD MS, Patricia Alonso-Galbán MD MS, \\ Moisés Díaz-Amaya, Samuel Hernández, Raúl Herrera-Valdés MD PhD DrSc, Luis Carlos Silva-Aycaguer PhD DrSc
}

\begin{abstract}
INTRODUCTION Chronic kidney disease has reached epidemic levels in several Central American countries since the early years of this century. In El Salvador, it is the second cause of death in men, the fifth in persons over 18 years old and the third cause of hospital deaths in the adult population. Its features, especially those of a subtype unassociated with traditional risk factors such as diabetes and high blood pressure, are only partially understood.
\end{abstract}

OBJECTIVE Estimate the magnitude of chronic kidney disease in the adult population of El Salvador, considering both prevalence of the disease in its diverse forms as well as presence of potential risk factors nationally and in major subpopulations.

METHODS A descriptive, cross-sectional analysis was conducted on data obtained from the Survey of Chronic Non-communicable Diseases in Adults in El Salvador, completed in 2015. The original data (interviews and measurements) were collected between October 2014 and March 2015 from 4817 adults employing a two-stage probabilistic cluster sample, with stratification of primary sampling units. Our analysis, using 20 of the 118 primary variables included in the original survey, focused on point estimation of prevalence rates and means, related to both traditional biological risk factors and nontraditional ones, such as insufficient hydration, strenuous working conditions and exposure to toxic agents. A separate analysis was performed to estimate prevalence of chronic kidney disease from nontraditional

\section{INTRODUCTION}

According to a 2018 report, the crude global prevalence of chronic kidney disease (CKD) rose by $87 \%$ between 1990 and 2016 and mortality from this cause doubled. In 2016, CKD was eleventh on the list of leading global causes of death.[1]

Non-communicable diseases have become the main causes of premature and preventable death in the Americas.[2] CKD is one of the most important, involving irreversible damage to kidney function and thus representing a serious health problem. Once established, the disease tends to progress to chronic kidney failure (CKF) or end-stage renal disease, requiring expensive renal replacement therapies (dialysis) or organ transplantation.[3] In the absence of such interventions, death is inevitable.[4]

Following a 2002 report on CKD in El Salvador,[5] various publications have described the emergence of a CKD epidemic in Central America starting early in this century.[6-9] It is estimated

IMPORTANCE For the first time by means of a national probabilistic sample, this analysis reveals a chronic kidney disease epidemic of massive and unprecedented proportions in El Salvador. causes. Corresponding confidence intervals were calculated with proper weighting

RESULTS The general prevalence of chronic kidney disease in EI Salvador was $12.8 \%$ (men $18.0 \%$; women $8.7 \%$ ). Of the chronically ill kidney patients, $13.1 \%$ were between 20 and 40 years of age. Among biological risk factors, the most frequent was high blood pressure $(37.0 \%)$. Among nontraditional risk factors, high levels of sugary drink consumption $(81.0 \%)$, insufficient hydration $(65.9 \%)$ and high levels of exposure to agrochemicals in the work environment (12.6\%) were also observed. Prevalence of chronic kidney disease from nontraditional causes was $3.9 \%$ (men $6.1 \%$; women $2.2 \%$ ).

CONCLUSIONS Chronic kidney disease has reached epidemic proportions in El Salvador. The data confirm a health tragedy that, although especially striking older men, also takes a severe toll on young men and women. The results confirm findings of previous research in several Salvadoran agricultural communities. The relatively high level of population exposure to agrochemicals is important and alarming, especially in rural areas, meriting health-impact studies that include and go beyond possible impact on chronic kidney disease.

KEYWORDS Kidney, renal insufficiency, chronic, risk factors, epidemics, El Salvador

that the disease has caused at least 20,000 premature deaths in men across the region.[9] PAHO notes that between 1997 and 2013 in Central America more than 60,000 deaths were due to kidney problems (KDN18 according to the International Statistical Classification of Diseases and Health Related Problems, Tenth Edition, ICD-10).[10] Of those deaths, $41.0 \%$ corresponded to persons aged $\leq 60$ years.[11]

These values are extremely high in the context of the Americas. [11] Although El Salvador and Nicaragua have the highest mortality rates (47.4 and 33.7 per 100,000 population, respectively), the situation is also alarming in areas of Guatemala, Honduras and Costa Rica.[12] According to a study carried out under PAHO auspices,[13] the greatest contrast in mortality rates for 1997-2003 is between El Salvador (47.4 per 100,000) and Cuba $(2.7$ per 100,000).

Epidemiological knowledge of CKD is fragmentary. It is a serious health problem in EI Salvador, where CKD is the second cause of death in men and the fifth in persons aged $>18$ years. The CKD death rate increased by $153 \%$ between 1997 and 2012.[14] In its annual report for 2012-2013, the Salvadoran Ministry of Health (MINSAL) declared CKD as the third leading cause of hospital deaths in the adult population: the first for men and the fifth for women, with a fatality rate of $12.6 \%$.[14]

For over a decade, a severe and premature form of CKD has reached epidemic proportions in Central America's agricultural com- 
munities, especially in Nicaragua and El Salvador.[11,13,15-18] Among other labels, it has been termed "chronic kidney disease of nontraditional etiology" (CKDnT),[13] as its causes are unrelated to the traditional risk factors for kidney disease-mainly diabetes mellitus (DM) and high blood pressure (HBP), but also proteinuria, glomerular diseases, systemic erythematous lupus, polycystic kidneys and obstructive uropathies.[19]

Although it has also been denominated CKD of unknown etiology (CKDu), in our analysis it will be called CKDnT to stress that not knowing the causes of a disease is not the same as knowing what does not cause it. While the exact cause of the disease cannot be known for a specific patient, in this epidemic we do know what has not caused CKD for a large number of patients. Valuable information is available from epidemiologic and clinical studies in Salvadoran farming communities.[20-22] Their results show high presence of CKDnT in rural areas, especially in male farmers aged $<60$ years and, to a lesser extent, in women, children and adolescents.[23] Among the main risk factors found in these studies, exposure to agrochemicals and insufficient hydration under exhausting working conditions stand out, as do the occupation of "farmer", as well as male sex, age, family history of CKD, and consumption of non-steroid anti-inflammatory drugs.

High-level meetings have been convened to address this health tragedy. In the San Salvador Declaration of 2013,[24] the Council of Ministers of Health of Central America and the Dominican Republic (COMISCA)[25] recognized CKDnT as a serious public health problem requiring urgent and coordinated action. In September of that year, the 52nd meeting of PAHO's Directing Council adopted a resolution on CKD in Central American agricultural communities in support of the San Salvador Declaration. [26] Ranking medical journals have echoed the concerns raised in these pronouncements.[27] Since then, greater attention has been focused on epidemiological studies of the problem's magnitude and location.

With the aim of providing a more complete assessment of CKD prevalence, the present study uses a CKD-specific methodological framework to estimate the magnitude of the epidemic in El Salvador's adult population, considering prevalence of the disease in its various forms and possible risk factors nationally and in selected subpopulations.

\section{METHODS}

The most complete dataset available for epidemiological research on CKD in El Salvador is from the National Survey of Chronic Noncommunicable Diseases in Adults in El Salvador (ENECA-ELS 2015).[28] With a sample of nearly 5000 subjects, representative of the entire adult population ( $\geq 20$ years of age), this research effort was distinguished by its methodological rigor, especially because all measurements were performed using internationally recommended methods. Due to its importance and its bearing on the present study, we briefly describe the ENECA-ELS 2015 sample design and some of its key methodological details first, followed by a similar description of design and methods for the present study.

ENECA-ELS 2015[28] A two-staged cluster sample design was employed with stratification of first-stage units. Primary sampling units (PSU) almost always corresponded to census tracts, though sometimes several tracts were joined to yield PSUs of similar size. Each sample segment included 150-250 households. Stratification prior to PSU selection was based on urban/rural residency, as well as geographic distribution throughout the country's five regions according to the latest national population and households census conducted in 2007. In selected PSUs within each of the ten strata formed by the crossing of these two axes, households were selected (secondary sampling units) and, finally, all individuals corresponding to the target population residing in them were included in the sample. In each of its phases, selection was carried out applying probabilistic techniques.

Inclusion criteria All persons aged $\geq 20$ years, residing in each selected household and providing written informed consent to participate in the study.

Exclusion criteria Persons with limitations preventing them from understanding the contents of the questionnaire and/or the research objectives.

Sample Of the 9097 persons originally included in the selected households, it was possible to study 6150 , although some only partially. Both interviews and measurements, including serum and urine laboratory tests, were completed for 4817 participants, representing a response rate of $67.6 \%$.

Data collection ENECA-ELS 2015 included epidemiologic and clinical data obtained through a structured individual questionnaire and biometric tests, completed from October 2014 through March 2015. A questionnaire adapted to the research purposes was prepared, using as references the WHO STEPwise methodology[29] and the US National Health and Nutrition Examination Survey (NHANES) carried out by the US Centers for Disease Control.[30]

\section{Measurement of physical and laboratory variables}

Blood pressure was measured with a digital sphygmomanometer (RIESTER model RI-Champion, Germany) with a precision of \pm 3 $\mathrm{mm} \mathrm{Hg}$ (cuff pressure) and $\pm 5 \%$ pulse frequency.

Blood biochemical determinations of creatinine, glycaemia, total cholesterol, HDL, LDL and triglycerides Measurements were taken after an 8-hour fast. They were performed in blood using calibrated state-of-the-art dry chemistry analyzers (REFLOTRON PLUS, Switzerland) under strict quality controls. Creatinine measurement was not recalibrated by isotope dilution mass spectrometry (IDMS).

Albuminuria and creatininuria were determined by the albumin-tocreatinine ratio (ACR) (CLINITEK Microalbumin 2, USA).

Quality control, standard procedures and data validation All medical instruments and supplies were calibrated. Laboratory analyses included the appropriate controls and were performed according to manufacturers' specifications. Specialized, certified personnel were in charge of measurements and analyses. The interviewer and then the fieldwork supervisor coded and examined information obtained from questionnaires. Whenever possible, data were collected using electronic devices to minimize transcription and typing errors;[31] data cleaning was performed daily by questionnaire supervisors and through random checks on $20 \%$ of cases.

Ethical considerations The study was designed and carried out according to the Helsinki Declaration of the World Medical Association. 
[32] Written informed consent was obtained from all participants, who agreed to use of their data under conditions of confidentiality. All participants with detected abnormalities received clinical followup. The study was conducted at the request of MINSAL and the research protocol was approved by the National Clinical Research Committee of El Salvador, of the Higher Council of Public Health.

Funding The ENECA-ELS 2015 study was funded by El Salvador's National Institute of Health-Ministry of Health (INS/MINSAL) and Solidarity Health Fund (FOSALUD), the Spanish Agency for International Development Cooperation (AECID), the US Centers for Disease Control (CDC) and PAHO. It also received methodological support from Cuba's Institute of Nephrology, National School of Public Health and Ministry of Public Health.

THE CKD STUDY The present analysis draws upon the descriptive data collected by ENECA-ELS 2015.[28]

Variables Of the 118 primary variables in the full dataset, our analysis used a subset of 20 selected for their relevance to CKD diagnosis or characterization, or because they provided stratification criteria for subgroup estimations (Table 1). The criteria for CKD presented in Table 1 are those listed in the International Society of Nephrology's guidelines for improving global CKD outcomes (KDIGO, Kidney Disease Improving Global Outcomes).[33,34] A study's adherence to these standards should be taken into account when assessing reported prevalence rates. PAHO[13] and NHANES[30] follow KDIGO criteria to identify CKD.

CKD is established in a single measurement whenever the glomerular filtration rate (GFR) is $<60$. When the GFR is $\geq 60$ and the ACR is $\geq 30$, another ACR measurement of $\geq 30$ separated by at least 3 months is required for CKD diagnosis, thus discarding subjects with circumstantial acute kidney disease. Studies that fail to take a second ACR measurement risk including persons with circumstantial acute kidney dysfunction in the CKD category, and will consequently report higher CKD prevalence. Consistent with International Society of Nephrology guidelines, we defined chronic kidney failure (CKF) as GFR $<60 \mathrm{~mL} / \mathrm{min} / 1.73 \mathrm{~m}^{2} \mathrm{SC}$ (or >CKD 2).

Statistical analysis Relevant information from the ENECA-ELS was analyzed
Table 1: Study variables

\begin{tabular}{|c|c|}
\hline Variable & Description \\
\hline Age & By age group in years $(20-40,41-60,>60)$ \\
\hline Sex & Male, female \\
\hline $\begin{array}{l}\text { Educational level } \\
\text { completed }\end{array}$ & No schooling or less than primary, primary, secondary, higher \\
\hline Urban-rural residence & Urban, rural \\
\hline Current occupation & Farmer, not farmer \\
\hline $\begin{array}{l}\text { Chronic kidney disease } \\
\text { (CKD)[34] }\end{array}$ & $\begin{array}{l}\text { CKD if one or both of the following characteristics is present: } \\
\text { 1) GFR }<60 \mathrm{~mL} / \mathrm{min} / 1.73 \mathrm{~m}^{2} \mathrm{SC} \\
\text { 2) GFR } \geq 60 \mathrm{~mL} / \mathrm{min} / 1.73 \mathrm{~m}^{2} \mathrm{SC} \text { and } \mathrm{ACR} \text { which reveals persistent } \\
\text { A2 or } \mathrm{A} 3 \text { albuminuria level }\end{array}$ \\
\hline
\end{tabular}

Family history of chronic kidney disease (CKD)

Present if the father or mother had suffered the disease

Water consumption

Sufficient: self-reported consumption of $\geq 2$ liters a day Insufficient: otherwise

High consumption of non-steroidal anti-inflammatory drugs (NSAID)

Yes: self-reported daily consumption of any of the following medications for at least one month in the past year: aspirin, ibuprofen, naproxen sodium, desketopropoxifen, indomethacin, ketorolac, diclofenac, celecoxib, meloxicam No: otherwise

Yes: self-reported consumption of one or more of the following

Consumption of sugary drinks beverages: hydrating beverages, soft drinks and processed juices, energy drinks, light beverages, processed tea No: otherwise

Intense occupational Yes: self-reported occupation as at least one of the following occupations: pesticide applicator (or exterminator), mixer or exposure to agrochemicals formulator of pesticides, flagman

No: otherwise

Hypertensive: known high blood pressure (self-reported or diagHigh blood pressure (HBP) nosed by a physician before the study) or HBP diagnosed during the study $(B P \geq 140 / 90)$ Not hypertensive

Diabetic: known DM (self-reported or diagnosed by a physician before the study) or DM diagnosed during the study (glycemia $\geq 126 \mathrm{mg} / \mathrm{dL}$ at random or $\geq 200 \mathrm{mg} / \mathrm{dL}$ with symptoms) Not diabetic

Albumin-to-creatinine ratio (ACR)

A1: $<30 \mathrm{mg} / \mathrm{g}$ (normal or slightly increased)

A2: $30-300 \mathrm{mg} / \mathrm{g}$ (moderately increased)

A3: $>300 \mathrm{mg} / \mathrm{g}$ (severely increased)

Glomerular filtration rate (GFR)

GFR $\left(\mathrm{mL} / \mathrm{min} / 1.73 \mathrm{~m}^{2}\right)$ was calculated from serum creatinine (SC) using the dry chemistry method and applying the CKD-Epi mathematical formula.[33]

Stage 1: GFR $\geq 90 \mathrm{~mL} / \mathrm{min} / 1.73 \mathrm{~m}^{2} \mathrm{SC}$ and ACR A2 or A3

Stage 2: GFR 60 to $\leq 89$ and ACR A2 or A3

CKD stage[34]

Stage 3a: GFR 45 to $\leq 59$

Stage 3b: GFR 30 to $\leq 44$

Stage 4: GFR 15 to $\leq 29$

Stage 5: GFR $<15$

Chronic kidney disease of nontraditional causes (CKDnT)

\section{Presence of CKD without HBP or DM}

Stage 1: GFR $\geq 90 \mathrm{~mL} / \mathrm{min} / 1.73 \mathrm{~m}^{2} \mathrm{SC}$ and ACR A2 or A3

Stage 2: GFR 60 to $\leq 89$ and ACR A2 or A3

CKDnT stage

Stage 3a: GFR 45 to $\leq 59$

Stage 3b: GFR 30 to $\leq 44$

Stage 4: GFR 15 to $\leq 29$

Stage 5: GFR $<15$

Chronic kidney failure

(CKF)

CKD at stage $>2$

Chronic kidney failure

of nontraditional causes

(CKFnT)
CKDnT at stage $>2$ 
with SPSS version 24 statistical program (Complex Samples module) for Windows (SPSS Inc, Illinois, USA) and EPIDAT 4.2.[35]

In keeping with the descriptive nature of a cross-sectional study, analysis focused on point estimations of prevalence rates and means, and calculation of respective confidence intervals. Since definitions of CKD and CKDnT used in this study adhere to KDIGO guidelines (Table 1), all CKD prevalence estimates included a second ACR measurement. This allowed for valid comparisons of results with those of other studies.

All estimates (point and interval) were made considering adequate weightings (derived from the non-equiprobabilistic nature of the sample and the need to calibrate "non-response") $[36,37]$ as well as the complex structure of the sample design. Estimates were made both for overall population and according to characteristics of selected population groups (according to urban/rural setting, occupation, age and sex). All results previously obtained by MINSAL[28] were recalculated after conducting a final database validation.

\section{RESULTS}

Sociodemographic characteristics of the sample Mean age of interviewees was 44.9 years $(95 \% \mathrm{Cl} 44.2-45.7)$ and slightly fewer than half $(45.4 \%)$ were aged $20-40$ years. Education level was predominantly low $(70.8 \%$ had completed primary school or less). Most resided in urban areas (58.6\%) and about 1 in 5 worked as farmers (Table 2).

Prevalence of CKD risk factors Table 3 summarizes prevalence estimates by sex, age group, urban/rural residence and current occupation. Among the traditional, biological risk factors, the most frequent was HBP (estimated prevalence $37.0 \%$ ), followed by DM (12.5\%). Prevalence was similar for men and women, and higher in the older age groups. Family history of CKD was found in $8.7 \%$ of the study population. All biological

Table 2: Sociodemographic characteristics of the sample studied. ENECA-ELS 2015

\begin{tabular}{|c|c|c|c|c|}
\hline \multicolumn{2}{|l|}{ Variable } & \multirow{2}{*}{$\begin{array}{c}n \\
3111\end{array}$} & \multirow{2}{*}{$\begin{array}{r}\begin{array}{l}\text { Weighted } \\
\text { percentage }\end{array} \\
56.8\end{array}$} & \multirow{2}{*}{$\begin{array}{l}95 \% \mathrm{CI} \\
54.9-58.7\end{array}$} \\
\hline Sey & Female & & & \\
\hline (6) & Male & 1706 & 43.2 & $41.3-45.1$ \\
\hline \multirow{3}{*}{$\begin{array}{l}\text { Age group } \\
\text { (years) }\end{array}$} & $20-40$ & 2235 & 45.4 & $43.0-47.8$ \\
\hline & $41-60$ & 1605 & 34.4 & $32.4-36.5$ \\
\hline & $>60$ & 977 & 20.2 & $18.5-22.1$ \\
\hline \multirow{2}{*}{$\begin{array}{l}\text { Urban/rural } \\
\text { residence }\end{array}$} & Urban & 2551 & 58.6 & $53.7-63.4$ \\
\hline & Rural & 2266 & 41.4 & $36.6-46.3$ \\
\hline \multirow{4}{*}{$\begin{array}{l}\text { Education } \\
\text { level } \\
\text { completed }\end{array}$} & No schooling & 1045 & 19.3 & $17.3-21.3$ \\
\hline & Primary & 2418 & 51.5 & $48.9-54.1$ \\
\hline & Secondary & 890 & 20.1 & 18.6-21.6 \\
\hline & Higher & 348 & 9.1 & $6.8-11.4$ \\
\hline \multirow{2}{*}{$\begin{array}{l}\text { Current } \\
\text { occupation }\end{array}$} & Farmer & 877 & 18.9 & $16.6-21.2$ \\
\hline & Not farmer & 3940 & 81.1 & $78.8-83.4$ \\
\hline
\end{tabular}

ENECA-ELS: National Survey of Chronic Non-communicable Diseases in Adults in El Salvador[28]

aSome data are slightly different from previously reported by MINSAL[28] because they were recalculated following a subsequent database validation risk factors were more prevalent among urban residents and non-farmers, with a greater difference in the case of hypertension in the first group and DM in the second.

Among the nontraditional CKD risk factors, high prevalence of sugary drink consumption (81.0\%) and insufficient water consumption $(65.9 \%)$ were observed. Insufficient water consumption was approximately 10 percentage points higher in those aged $>60$ years relative to the other two age groups, much higher in women $(75.3 \%)$, and noticeably lower in farmers. Sugary drink consumption showed an opposite pattern: lower in the older age groups and higher in men and farmers. Consumption of NSAID's was low and fairly similar among stratifying variables.

Regarding toxic exposure, it was estimated that more than 1 in 10 persons were intensely exposed to agrochemicals $(12.6 \%)$ at work. Level of exposure was higher in men $(23.0 \%)$, farmers $(14.7 \%)$ and rural residents $(16.5 \%)$ and increased moderately with age.

Prevalence of CKD and CKDnT Estimated CKD prevalence in the Salvadoran adult population, considering the two ACR measurements, was $12.8 \%$, representing an estimated population of nearly half a million adults (Table 4). Considering only one ACR measurement, prevalence reached $28.1 \%$ (95\% Cl 26.1-30.1), or over 1 million adults.

Estimated CKD prevalence in men was more than double that in women and increased with age, reaching one in every three Salvadorans of either sex aged $>60$ years. However, most noteworthy is the high prevalence of the disease in the younger adult population ( $<60$ years), at $7.1 \%(95 \% \mathrm{Cl} 5.8-8.4)$. Overall national prevalence of CKF was $8.5 \%$, notably higher in those aged $>60$ years and markedly higher in men. Higher levels of CKD and CKF were observed in farmers, relative to those in other occupations (Table 4). Of the CKD cases detected, 30.5\% (95\% Cl 25.9-35.5) classified as CKDnT, $33.9 \%$ in men $(95 \% \mathrm{Cl} 28.1-40.2)$ and $25.1 \%$ in women $(95 \% \mathrm{Cl} 19.2-32.1)$.

CKDnT national prevalence was 3.9\%, representing an estimated population of some 140,000 adults. Among those aged $>60$ years, CKDnT prevalence was very high, affecting 1 out of every 11 Salvadorans. CKDnT and CKFnT prevalences among farmers surpassed those found among non-agricultural workers (Table 4). The mean age of those with CKD $(61.3,95 \% \mathrm{Cl} 59.3-63.4)$ was almost 6 years higher than those with CKDnT $(55.5,95 \% \mathrm{Cl}$ 51.8-59.2).

In general, more advanced stages of CKD had lower prevalence. The lowest was stage 5-requiring renal replacement therapy-at $0.7 \%$, representing $\pm 26,000$ adults (Table 5 ). A similar pattern of disease stages was observed for CKDnT (Table 6).

Data shown in tables are slightly different from those previously reported by MINSAL,[28] because all estimates were recalculated after a thorough database validation.

\section{DISCUSSION}

Comparison of CKD prevalence estimates across diverse temporal or geographic contexts should take into account the criteria adopted to define CKD and the methods used to assess kidney 
Table 3: Prevalence* of biological and nontraditional risk factors for CKD in the Salvadoran adult population, by selected variables. ENECAELS 2015

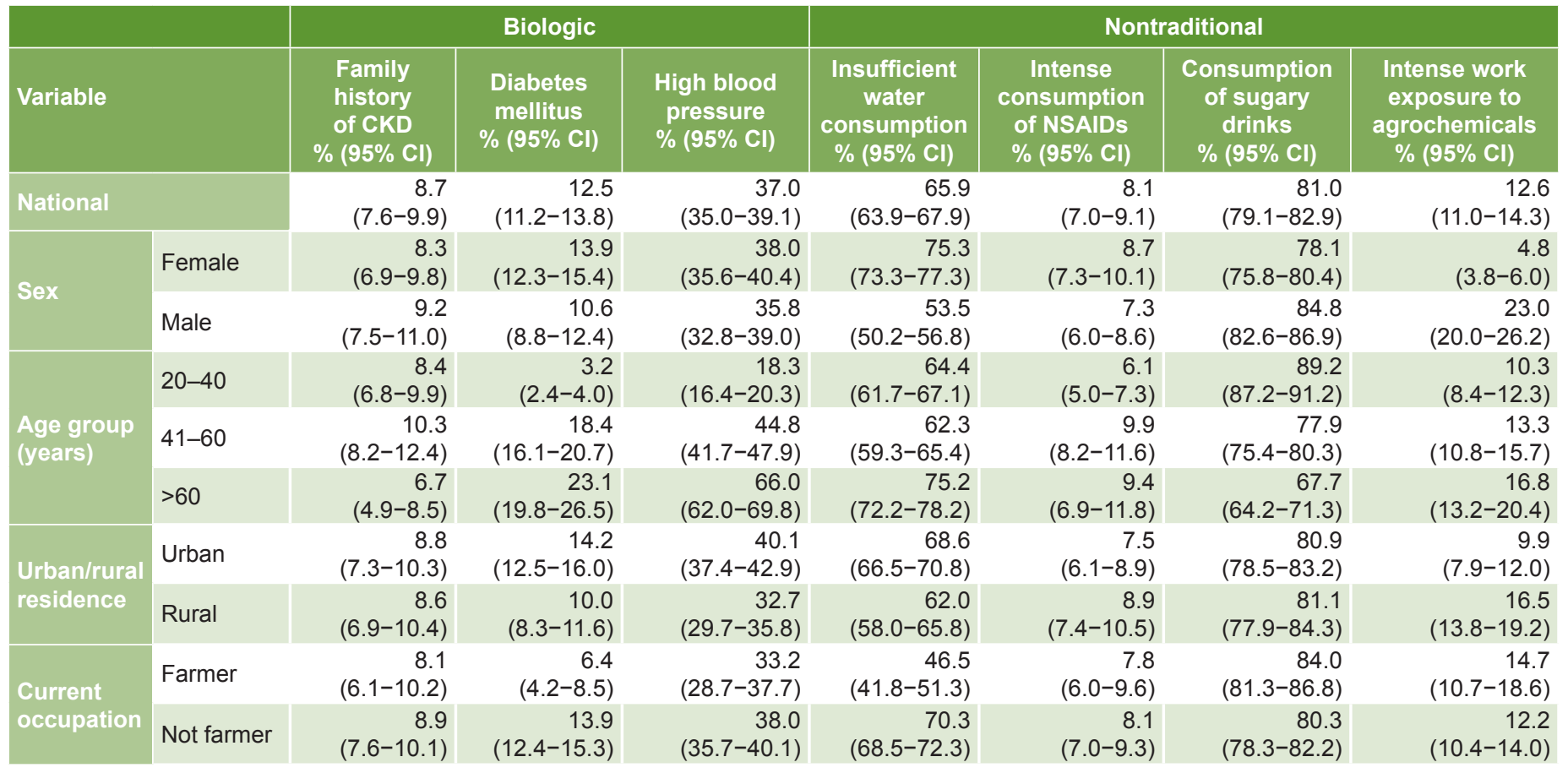

* Weighted estimates

CKD: chronic kidney disease; ENECA-ELS: National Survey of Chronic Non-communicable Diseases in Adults in El Salvador;[28] NSAIDs: Non-steroid antiinflammatory drugs

aSome data are slightly different from those previously reported by MINSAL[28] because they were recalculated after a subsequent validation of the database

Table 4: Prevalence* of CKD, CKF, CKDnT and CKFnT by selected variables in the Salvadoran adult population. ENECA-ELS 2015

\begin{tabular}{|c|c|c|c|c|c|}
\hline \multicolumn{2}{|l|}{ Variable } & $\begin{array}{c}\text { CKD } \\
\% \\
(95 \% \text { Cl) }\end{array}$ & $\begin{array}{c}\text { CKF } \\
\% \\
(95 \% \text { CI) }\end{array}$ & $\begin{array}{c}\text { CKDnT } \\
\% \\
(95 \% \mathrm{CI})\end{array}$ & $\begin{array}{c}\text { CKFnT } \\
\% \\
(95 \% \text { CI) }\end{array}$ \\
\hline \multicolumn{2}{|l|}{ National } & $\begin{array}{r}12.8 \\
(11.2-14.4)\end{array}$ & $\begin{array}{r}8.5 \\
(7.2-9.9)\end{array}$ & $\begin{array}{r}3.9 \\
(3.1-4.8)\end{array}$ & $\begin{array}{r}2.4 \\
(1.7-3.0)\end{array}$ \\
\hline \multirow{2}{*}{ Sex } & Female & $\begin{array}{r}8.7 \\
(7.2-10.3)\end{array}$ & $\begin{array}{r}5.0 \\
(3.9-6.2)\end{array}$ & $\begin{array}{r}2.2 \\
(1.6-2.8)\end{array}$ & $\begin{array}{r}1.0 \\
(0.5-1.4)\end{array}$ \\
\hline & Male & $\begin{array}{r}18.0 \\
(15.2-20.7)\end{array}$ & $\begin{array}{r}13.2 \\
(10.7-15.6)\end{array}$ & $\begin{array}{r}6.1 \\
(4.5-7.6)\end{array}$ & $\begin{array}{r}4.2 \\
(2.9-5.5)\end{array}$ \\
\hline \multirow{3}{*}{$\begin{array}{l}\text { Age group } \\
\text { (years) }\end{array}$} & $20-40$ & $\begin{array}{r}3.7 \\
(2.5-4.9)\end{array}$ & $\begin{array}{r}1.3 \\
(0.7-1.9)\end{array}$ & $\begin{array}{r}2.4 \\
(1.5-3.2)\end{array}$ & $\begin{array}{r}0.7 \\
(0.3-1.1)\end{array}$ \\
\hline & $41-60$ & $\begin{array}{r}11.7 \\
(9.6-13.8)\end{array}$ & $\begin{array}{r}7.3 \\
(5.5-9.1)\end{array}$ & $\begin{array}{r}3.0 \\
(2.0-4.0)\end{array}$ & $\begin{array}{r}1.9 \\
(1.1-2.6)\end{array}$ \\
\hline & $>60$ & $\begin{array}{r}35.5 \\
(31.0-40.0)\end{array}$ & $\begin{array}{r}26.9 \\
(22.9-30.1)\end{array}$ & $\begin{array}{r}8.9 \\
(6.3-11.6)\end{array}$ & $\begin{array}{r}7.0 \\
(4.6-9.3)\end{array}$ \\
\hline \multirow{2}{*}{$\begin{array}{l}\text { Urban/rural } \\
\text { residence }\end{array}$} & Urban & $\begin{array}{r}11.4 \\
(9.2-13.6)\end{array}$ & $\begin{array}{r}8.2 \\
(6.4-10.0)\end{array}$ & $\begin{array}{r}3.2 \\
(2.1-4.3)\end{array}$ & $\begin{array}{r}2.2 \\
(1.3-3.0)\end{array}$ \\
\hline & Rural & $\begin{array}{r}14.7 \\
(12.2-17.1)\end{array}$ & $\begin{array}{r}9.0 \\
(7.0-10.1)\end{array}$ & $\begin{array}{r}4.9 \\
(3.4-6.3)\end{array}$ & $\begin{array}{r}2.6 \\
(1.5-3.8)\end{array}$ \\
\hline \multirow{2}{*}{$\begin{array}{l}\text { Current } \\
\text { occupation }\end{array}$} & Farmer & $\begin{array}{r}18.4 \\
(14.8-22.0)\end{array}$ & $\begin{array}{r}12.9 \\
(9.5-16.3)\end{array}$ & $\begin{array}{r}7.5 \\
(4.9-10.1)\end{array}$ & $\begin{array}{r}5.0 \\
(2.7-7.3)\end{array}$ \\
\hline & Not farmer & $\begin{array}{r}11.4 \\
(9.8-13.1)\end{array}$ & $\begin{array}{r}7.5 \\
(6.2-8.8)\end{array}$ & $\begin{array}{r}3.0 \\
(2.3-3.8)\end{array}$ & $\begin{array}{r}1.7 \\
(1.2-2.3)\end{array}$ \\
\hline
\end{tabular}

* Weighted estimates

CKD: Chronic kidney disease; CKF: Chronic kidney failure; CKDnT: nontraditional chronic kidney disease; CKFnT: nontraditional chronic kidney failure; ENECA-ELS: National Survey of Chronic Non-communicable Diseases in Adults in El Salvador[28]

All rates were estimated taking into account the two ACR measurements carried out to confirm chronicity function.[38,39] Despite the Kidney Disease Outcomes Quality Initiative (K/DOQI) CKD guidelines published in 2002 and updated in 2012,[34,39] definitions of CKD and the cut-off values for GFR and albuminuria vary noticeably. A recent systematic review examining 48 papers published between January 1, 2003 and November 1, 2014, reporting CKD prevalence for the general adult population in 20 European countries, found that no study used the KDIGO specificities for confirming chronicity.[38]

The CKD epidemic in the adult population of $\mathrm{EI}$ Salvador is characterized by very high prevalence, if we consider that the definition of CKD includes confirmation of chronicity as prescribed in KDIGO guidelines.[34] However, this figure is lower than that found in studies carried out in El Salvador's agricultural communities by INS/MINSAL, in which chronicity of kidney disease was also verified.[20] In those cases, CKD prevalence of $15.4 \%-21.1 \%$ was reported and, when diagnosis was confirmed after 3 months, a CKF prevalence of $8.8 \%-13.3 \%$. $[8,16,21,40]$ When prevalence in our study was estimated using a single measurement, the value obtained was even higher $(28.1 \%)$. Regarding other countries of the region, it should be noted that in $\mathrm{Ni}-$ caragua, prevalence rates of up to $42 \%$ in men and $9.8 \%$ in women have been reported in some areas. [41] High rates elsewhere in the region also point to an outbreak of the epidemic.[42] 
Table 5: Prevalence* of chronic kidney disease stages by sex, age group, urban/rural and current occupation, in El Salvador's adult population. ENECA-ELS 2015

\begin{tabular}{|c|c|c|c|c|c|c|c|}
\hline \multirow[t]{2}{*}{ Variable } & & \multicolumn{6}{|c|}{$\begin{array}{l}\text { Prevalence of chronic kidney disease by stage } \\
\qquad \%(95 \% \mathrm{Cl})\end{array}$} \\
\hline & & CKD 1 & CKD 2 & CKD 3a & CKD 3b & CKD 4 & CKD 5 \\
\hline \multicolumn{2}{|l|}{ National } & $\begin{array}{r}1.8 \\
(1.3-2.4)\end{array}$ & $\begin{array}{r}1.6 \\
(1.2-2.1)\end{array}$ & $\begin{array}{r}4.4 \\
(3.6-5.4)\end{array}$ & $\begin{array}{r}2.7 \\
(2.1-3.5)\end{array}$ & $\begin{array}{r}1.3 \\
(0.9-1.8)\end{array}$ & $\begin{array}{r}0.7 \\
(0.4-1.1)\end{array}$ \\
\hline \multirow{2}{*}{ Sex } & Female & $\begin{array}{r}1.5 \\
(1.0-2.2)\end{array}$ & $\begin{array}{r}1.6 \\
(1.1-2.1)\end{array}$ & $\begin{array}{r}3.0 \\
(2.0-4.0)\end{array}$ & $\begin{array}{r}1.4 \\
(1.0-1.9)\end{array}$ & $\begin{array}{r}0.9 \\
(0.4-1.4)\end{array}$ & $\begin{array}{r}0.2 \\
(0.0-0.4)\end{array}$ \\
\hline & Male & $\begin{array}{r}2.2 \\
(1.3-3.1)\end{array}$ & $\begin{array}{r}1.7 \\
(1.1-2.3)\end{array}$ & $\begin{array}{r}6.3 \\
(4.8-7.8)\end{array}$ & $\begin{array}{r}4.5 \\
(3.3-5.8)\end{array}$ & $\begin{array}{r}1.9 \\
(1.1-2.7)\end{array}$ & $\begin{array}{r}1.4 \\
(0.7-2.0)\end{array}$ \\
\hline \multirow{3}{*}{$\begin{array}{l}\text { Age group } \\
\text { (years) }\end{array}$} & $20-40$ & $\begin{array}{r}1.9 \\
(1.1-2.7)\end{array}$ & $\begin{array}{r}0.4 \\
(0.1-0.6)\end{array}$ & $\begin{array}{r}0.8 \\
(0.3-1.2)\end{array}$ & $\begin{array}{r}0.2 \\
(0.0-0.4)\end{array}$ & $\begin{array}{r}0.3 \\
(0.0-0.6)\end{array}$ & $\begin{array}{r}0.2 \\
(0.0-0.4)\end{array}$ \\
\hline & $41-60$ & $\begin{array}{r}2.2 \\
(1.4-3.1)\end{array}$ & $\begin{array}{r}1.4 \\
(0.8-2.1)\end{array}$ & $\begin{array}{r}3.7 \\
(2.5-4.9)\end{array}$ & $\begin{array}{r}1.9 \\
(0.9-2.8)\end{array}$ & $\begin{array}{r}1.5 \\
(0.8-2.3)\end{array}$ & $\begin{array}{r}0.9 \\
(0.3-1.6)\end{array}$ \\
\hline & $>60$ & $\begin{array}{r}1.0 \\
(0.3-1.7)\end{array}$ & $\begin{array}{r}4.9 \\
(3.4-6.5)\end{array}$ & $\begin{array}{r}14.2 \\
(11.1-17.3)\end{array}$ & $\begin{array}{r}10.3 \\
(7.7-13.0)\end{array}$ & $\begin{array}{r}3.5 \\
(2.1-4.9)\end{array}$ & $\begin{array}{r}1.6 \\
(0.7-2.5)\end{array}$ \\
\hline \multirow{2}{*}{$\begin{array}{l}\text { Urban/rural } \\
\text { residence }\end{array}$} & Urban & $\begin{array}{r}1.3 \\
(0.7-1.9)\end{array}$ & $\begin{array}{r}1.1 \\
(0.6-1.5)\end{array}$ & $\begin{array}{r}5.2 \\
(3.8-6.5)\end{array}$ & $\begin{array}{r}2.2 \\
(1.4-3.0)\end{array}$ & $\begin{array}{r}1.0 \\
(0.6-1.4)\end{array}$ & $\begin{array}{r}0.7 \\
(0.3-1.1)\end{array}$ \\
\hline & Rural & $\begin{array}{r}2.6 \\
(1.6-3.6)\end{array}$ & $\begin{array}{r}2.4 \\
(1.6-3.2)\end{array}$ & $\begin{array}{r}3.5 \\
(2.5-4.5)\end{array}$ & $\begin{array}{r}3.6 \\
(2.5-4.7)\end{array}$ & $\begin{array}{r}1.8 \\
(1.0-2.7)\end{array}$ & $\begin{array}{r}0.7 \\
(0.2-1.3)\end{array}$ \\
\hline \multirow{2}{*}{$\begin{array}{l}\text { Current } \\
\text { occupation }\end{array}$} & Farmer & $\begin{array}{r}2.5 \\
(1.4-3.6)\end{array}$ & $\begin{array}{r}2.2 \\
(1.1-3.2)\end{array}$ & $\begin{array}{r}6.2 \\
(4.3-8.1)\end{array}$ & $\begin{array}{r}4.1 \\
(2.5-5.8)\end{array}$ & $\begin{array}{r}2.5 \\
(1.2-3.9)\end{array}$ & $\begin{array}{r}0.9 \\
(0.0-1.8)\end{array}$ \\
\hline & $\begin{array}{l}\text { Not } \\
\text { farmer }\end{array}$ & $\begin{array}{r}1.7 \\
(1.1-2.2)\end{array}$ & $\begin{array}{r}1.5 \\
(1.1-2.0)\end{array}$ & $\begin{array}{r}4.0 \\
(3.1-5.0)\end{array}$ & $\begin{array}{r}2.5 \\
(1.7-3.2)\end{array}$ & $\begin{array}{r}1.1 \\
(0.7-1.5)\end{array}$ & $\begin{array}{r}0.7 \\
(0.4-1.0)\end{array}$ \\
\hline
\end{tabular}

*Weighted estimates

CKD: Chronic kidney disease; ENECA-ELS: National Survey of Chronic Non-communicable Diseases in Adults in El Salvador[28]

Table 6: Prevalence* of chronic kidney disease of nontraditional causes for each stage by sex, age group, urban/rural and current occupation, in EI Salvador adult population.

\section{ENECA-ELS 2015}

\begin{tabular}{|c|c|c|c|c|c|c|c|}
\hline \multirow[t]{2}{*}{ Variable } & & \multicolumn{6}{|c|}{$\begin{array}{c}\text { Prevalence of chronic kidney disease } \\
\text { of nontraditional causes by stage } \\
\qquad \%(95 \% \mathrm{Cl})\end{array}$} \\
\hline & & CKDnT 1 & CKDnT 2 & CKDnT 3a & CKDnT 3b & CKDnT 4 & CKDnT 5 \\
\hline \multicolumn{2}{|l|}{ National } & $\begin{array}{r}0.8 \\
(0.5-1.1)\end{array}$ & $\begin{array}{r}0.5 \\
(0.2-0.7)\end{array}$ & $\begin{array}{r}1.3 \\
(0.9-1.8)\end{array}$ & $\begin{array}{r}0.7 \\
(0.4-1.0)\end{array}$ & $\begin{array}{r}0.4 \\
(0.1-0.6)\end{array}$ & $\begin{array}{r}0.1 \\
(0.0-0.3)\end{array}$ \\
\hline \multirow{2}{*}{ Sex } & Female & $\begin{array}{r}0.7 \\
(0.4-1.1)\end{array}$ & $\begin{array}{r}0.3 \\
(0.0-0.5)\end{array}$ & $\begin{array}{r}0.5 \\
(0.2-0.9)\end{array}$ & $\begin{array}{r}0.3 \\
(0.0-0.6)\end{array}$ & $\begin{array}{r}0.2 \\
(0.0-0.4)\end{array}$ & - \\
\hline & Male & $\begin{array}{r}0.8 \\
(0.3-1.3)\end{array}$ & $\begin{array}{r}0.7 \\
(0.3-1.3)\end{array}$ & $\begin{array}{r}2.4 \\
(1.4-3.3)\end{array}$ & $\begin{array}{r}1.3 \\
(0.7-1.9)\end{array}$ & $\begin{array}{r}0.6 \\
(0.2-1.1)\end{array}$ & $\begin{array}{r}0.3 \\
(0.0-0.6)\end{array}$ \\
\hline \multirow{3}{*}{$\begin{array}{l}\text { Age group } \\
\text { (years) }\end{array}$} & $20-40$ & $\begin{array}{r}1.3 \\
(0.7-1.9)\end{array}$ & $\begin{array}{r}0.3 \\
(0.1-0.6)\end{array}$ & $\begin{array}{r}0.4 \\
(0.1-0.7)\end{array}$ & $\begin{array}{r}0.1 \\
(0.0-0.3)\end{array}$ & $\begin{array}{r}0.2 \\
(0.0-0.4)\end{array}$ & $\begin{array}{r}0.1 \\
(0.0-0.2)\end{array}$ \\
\hline & $41-60$ & $\begin{array}{r}0.3 \\
(0.1-0.5)\end{array}$ & $\begin{array}{r}0.5 \\
(0.1-1.0)\end{array}$ & $\begin{array}{r}1.3 \\
(0.6-1.9)\end{array}$ & $\begin{array}{r}0.3 \\
(0.0-0.5)\end{array}$ & $\begin{array}{r}0.5 \\
(0.0-1.0)\end{array}$ & $\begin{array}{r}0.1 \\
(0.0-0.2)\end{array}$ \\
\hline & $>60$ & $\begin{array}{r}0.5 \\
(0.0-1.0)\end{array}$ & $\begin{array}{r}0.8 \\
(0.2-1.5)\end{array}$ & $\begin{array}{r}3.6 \\
(2.0-5.3)\end{array}$ & $\begin{array}{r}3.0 \\
(1.7-4.3)\end{array}$ & $\begin{array}{r}0.7 \\
(0.0-1.3)\end{array}$ & $\begin{array}{r}0.4 \\
(0.0-1.0)\end{array}$ \\
\hline \multirow{2}{*}{$\begin{array}{l}\text { Urban/rural } \\
\text { residence }\end{array}$} & Urban & $\begin{array}{r}0.5 \\
(0.2-0.8)\end{array}$ & $\begin{array}{r}0.3 \\
(0.0-0.5)\end{array}$ & $\begin{array}{r}1.5 \\
(0.8-2.2)\end{array}$ & $\begin{array}{r}0.4 \\
(0.1-0.7)\end{array}$ & $\begin{array}{r}0.3 \\
(0.0-0.5)\end{array}$ & $\begin{array}{r}0.2 \\
(0.0-0.5)\end{array}$ \\
\hline & Rural & $\begin{array}{r}1.1 \\
(0.5-1.7)\end{array}$ & $\begin{array}{r}0.8 \\
(0.3-1.3)\end{array}$ & $\begin{array}{r}1.1 \\
(0.6-1.7)\end{array}$ & $\begin{array}{r}1.2 \\
(0.6-1.7)\end{array}$ & $\begin{array}{r}0.6 \\
(0.1-1.0)\end{array}$ & 0.0 \\
\hline \multirow{2}{*}{$\begin{array}{l}\text { Current } \\
\text { occupation }\end{array}$} & Farmer & $\begin{array}{r}1.1 \\
(0.3-1.9)\end{array}$ & $\begin{array}{r}1.0 \\
(0.2-1.8)\end{array}$ & $\begin{array}{r}2.6 \\
(1.3-3.9)\end{array}$ & $\begin{array}{r}1.6 \\
(0.6-2.5)\end{array}$ & $\begin{array}{r}0.9 \\
(0.1-1.7)\end{array}$ & $\begin{array}{r}0.3 \\
(0.0-0.9)\end{array}$ \\
\hline & $\begin{array}{l}\text { Not } \\
\text { farmer }\end{array}$ & $\begin{array}{r}0.7 \\
(0.4-1.0)\end{array}$ & $\begin{array}{r}0.4 \\
(0.1-0.6)\end{array}$ & $\begin{array}{r}1.0 \\
(0.6-1.5)\end{array}$ & $\begin{array}{r}0.5 \\
(0.3-0.8)\end{array}$ & $\begin{array}{r}0.3 \\
(0.0-0.5)\end{array}$ & $\begin{array}{r}0.1 \\
(0.0-0.2)\end{array}$ \\
\hline
\end{tabular}

*Weighted estimates

CKDnT: Chronic kidney disease of non-traditional causes; ENECA-ELS: National Survey of Chronic Noncommunicable Diseases in Adults in El Salvador[28]
Comparing our findings with national statistics from other countries, mortality data lead us to assert that CKD is a health problem of epidemic magnitude in the adult population of El Salvador. Though El Salvador's CKD prevalence $(12.8 \%)$ was lower than other rates obtained by national studies conducted in the USA (16.8\%),[43,44] Japan (26.7\%)[45] and Australia (20.4\%),[46] none of these studies used the KDIGO definition for CKD chronicity, which prescribes a second measurement after 3 months. Nevertherless, other investigations that have not adhered to this criterion have found prevalence rates lower than those estimated for the Salvadoran population.[47-49]

This study brings to light the remarkable presence of CKDnT in the Salvadoran population: about 3 out of 10 adults diagnosed with CKD do not suffer HBP or DM. That is, CKDnT constitutes approximately one third of all CKD in El Salvador. The ratio CKDnT:CKD is similar for men and women: CKDnT rate for men is $6.0 \%$ (95\% Cl $4.6 \%-7.8 \%)$ and for women $2.1 \%(95 \% \mathrm{Cl} 1.6 \%-2.9 \%)$, while CKD rates were estimated at $18.8 \%$ and $8.7 \%$ respectively.

Although the highest CKD and CKDnT prevalences were found in persons aged $>60$ years, the difference between those above and below that age threshold is much smaller for CKDnT. This points to earlier onset of this form of the disease. This possibility, combined with high levels of nontraditional CKD risk factors (insufficient water consumption, high consumption of sugary drinks and intense occupational exposure to agrochemicals), should be considered when designing subsequent research aimed at identifying possible causal factors of El Salvador's CKD epidemic. Insufficient hydration is a general phenomenon, but the study shows that it is more pronounced among women than men, which calls for further scrutiny.

We note the very high prevalence of exposure to agrochemicals in the Salvadoran population (12.6\%). This risk factor was nearly 5 times higher in men than in women and 1.7 higher in rural areas. Though not surprising, these figures are alarming. Many results 
thus far published for both Central America[50-54] and countries in other regions, including Mexico, $[55,56]$ the USA[57,58] and Sri Lanka,[59,60] show that populations in agricultural communities most affected by the epidemic are directly or indirectly exposed to pesticides, herbicides and numerous toxic substances (heavy metals and metalloids) contained as impurities in certain agrochemicals and fertilizers (e.g. glyphosate, paraquat, carbofuran, deltamethrin, organophosphates). Many of these substances are banned in the countries where they are produced, and yet are in general use in others, occasionally mixed and frequently applied with little or no protection for those who handle them.[61]

The CKDnT epidemic has appeared in other parts of the world,[62] particularly in agricultural areas of Sri Lanka,[63,64] where it has been estimated that at least 400,000 persons suffer from the disease in the northern region[65] and prevalence could reach $21 \%$. [66] A similar pattern has been reported in southern India[67,68] and in other countries such as Saudi Arabia,[69] Egypt[70] and Senegal.[71] The health tragedies in Sri Lanka and El Salvador show pronounced similarities in practically all relevant parameters,[72-74] suggesting that the countries are facing the same epidemic.

This study has limitations; among them, that exposure data were based on study participants' reports, which often entails underreporting and recall bias. In addition, interviewing and measuring nearly 5000 persons under the highly hostile circumstances prevalent in El Salvador partially explains the anticipated substantial rate of non-response. However, from the quantitative point of view, the confidence intervals are narrow enough to produce reliable point estimates. While this loss of information could theoretically bias the estimates, non-response as well as the nonequiprobability of the sample were considered when constructing the weightings. On the other hand, this non-response can be considered unrelated to the real value of variables, since it was largely due to rejection of hundreds of cases-in some instances because informed consent was not unambiguously recorded, and in others because informal groups blocked access to households in the areas where they operated.

Despite these limitations, the importance of this paper lies in the fact that it reports the results of the first epidemiological investigation on the prevalence of CKD and CKDnT based on a nationally representative sample of adults. Its findings may serve as a valuable benchmark for present and future studies addressing the epidemic appearance of the disease, both in El Salvador and in the Central American region.

One of the principal strengths of the study is the application of the CKD definition accepted by the International Society of Nephrology[34] to a national-scale study conducted in a socially conflicted and violent area.

\section{CONCLUSIONS}

The results confirm previous research in El Salvador's agricultural communities: that CKD constitutes a health problem of epidemic magnitude in the adult population. This health tragedy especially strikes older men but is also present in young people of both sexes.

An important and alarming fact is that 1 out of 10 persons surveyed attested to being exposed to agrochemicals at work. This finding merits more detailed study, beyond its possible impact on CKD.

Reversing the epidemic can only be achieved through practical measures. Their identification and implementation require knowledge of the disease and its associated risk factors, which is the aim of this article. The topic is far from exhausted and, as argued in a recent paper,[75] demands further research. - 1h

\section{REFERENCES}

1. Xie $\mathrm{Y}$, Bowe B, Mokdad AH, Xian H, Yan Y, Li $\mathrm{T}$, et al. Analysis of the Global Burden of Disease study highlights the global, regional, and national trends of chronic kidney disease epidemiology from 1990 to 2016. Kidney Int. 2018 Sep;94(3):567-81.

2. Pan American Health Organization. Estrategia Regional y Plan de Acción para Un Enfoque Integrado Sobre la Prevención y el Control de las enfermedades Crónicas. Washington, D.C.: Pan American Health Organization; 2007. 46 p. Spanish.

3. Salas A, Hinojosa R, Battilana C. Costo de las terapias para tratar la Insuficiencia Renal Crónica Terminal (IRCT). Diagnóstico [Internet]. 2006 Oct-Dec [cited 2018 Sep 12];45(4). Available from: http://www.fihu-diagnostico.org.pe/revista/ numeros/2006/oct-dic/182-184.html. Spanish.

4. Fogarty DG, Taal MW. A stepped care approach to the management of chronic kidney disease. In: Skorecki K, Chertow GM, Marsden PA, Taal MW, Yu ASL, editors. Brenner and Rector's The Kidney. 10th ed. Philadelphia: Elsevier; 2016. Chapter 62. p. 1987-2026.

5. Trabanino RG, Aguilar R, Silva CR, Mercado $\mathrm{MO}$, Merino RL. Nefropatía terminal en pacientes de un hospital de referencia en El Salvador. Rev Panam Salud Pública [Internet]. 2002 [cited 2018 Sep12];12(3). Available from: http://www .scielosp.org/pdf/rpsp/v12n3/12875.pdf. Spanish.
6. Hoy H, Ordúñez P, editors. Epidemic of Chronic Kidney Disease in Agricultural Communities in Central America. Case definitions, methodological basis and approaches for public health surveillance. Washington, D.C.: Pan American Health Organization; 2017 Jun.

7. Wesseling C, Crowe J, Hagstedt C, Jakobsson $\mathrm{K}$, Lucas R, Wegman DH. The epidemic of chronic kidney disease of unknown etiology in Mesoamerica: a call for interdisciplinary research and action. Am J Public Health. 2013 Nov 3;103(11):1927-30.

8. Herrera Valdés R, Orantes CM, Almaguer López M, López Marín L, Arévalo PA, Smith González $M J$, et al. Clinical characteristic of chronic kidney disease of non-traditional causes in women of agricultural communities in El Salvador. Clin Nephrol. 2015;83(7 Suppl1):S56-63.

9. Ramírez Rubio O, McClean MD, Amador JJ, Brooks DR. An epidemic of chronic kidney disease in Central America: an overview. J Epidemiol Community Health. 2013 Jan;67(1):1-3.

10. World Health Organization. International Statistical Classification of Diseases and Related Health Problems I0th Revision (ICD10) [Internet]. Geneva: World Health Organization; 2010 [cited 2018 Sep 12]. 195 p. Available from: https://www.who.int/cla ssifications/icd/ICD10Volume2_en_2010.pdf.

11. Ordúñez $P$, Martínez R, Reveiz L, Chapman E, Sáenz C, Soares da Silva A, et al. Chronic kidney disease epidemic in Central América: urgent public health action is needed amid causal uncertainty. PLoS Negl Trop Dis. 2014 Aug 7;8(8):e3019.

12. Elinder CG, Annika O, Wernerson AO. Mesoamerican nephropathy [Internet]. Massachusetts: UptoDate, Wolters Kluwer Health Division; 2017 Apr 27 [cited 2018 Sep 12]. Available from: https://www.uptodate.com/contents/mesoame rican-nephropathy.

13. Lozier M, Turcios-Ruiz RM, Noonan G, Ordúñez $P$. Chronic kidney disease of nontraditional etiology in Central America: a provisional epidemiologic case definition for surveillance and epidemiologic studies. Rev Panam Salud Pública. 2016 Nov;40(5):294-300.

14. Ministry of Public Health and Social Assistance of El Salvador. Informe de Labores 2012-2013 [Internet]. San Salvador: Ministry of Public Health and Social Assistance of El Salvador; 2013 [cited 2018 Sep 12]. Available from: https://www .transparencia.gob.sv/institutions/minsal/docu ments/13867/download. Spanish.

15. Orantes CM, Herrera R, Almaguer M, Brizuela EG, Hernández CE, Bayarre $\mathrm{H}$, et al. Chronic kidney disease and associated risk factors in the Bajo Lempa region of El Salvador: Nefrolempa study, 2009. MEDICC Rev. 2011 Oct;13(4):14-22.

16. Almaguer M, Herrera R, Orantes CM. Chronic kidney disease of unknown etiology in ag- 
ricultural communities. MEDICC Rev. 2014 Apr;16(2):9-15.

17. Wesseling C, van Wendel B, Crowe J, Rittner R, Sanati NA, Hogstedt C, et al. Mesoamerican nephropathy: geographical distribution and time trends of chronic kidney disease mortality between 1970 and 2012 in Costa Rica. Occup Environ Med. 2015 Oct; 72(10):714-21.

18. García-Trabanino R, Domínguez J, Jansà JM, Oliver A. [Proteinuria and chronic renal failure in the coast of El Salvador: detection with low cost methods and associated factors]. Nefrologia. 2005;25(1):31-8. Spanish.

19. Centers for Disease Control and Prevention (CDC). National Chronic Kidney Disease Fact Sheet, 2017 [Internet]. Atlanta: U.S. Department of Health and Human Resources; Centers for Disease Control and Prevention (CDC); 2017 [cited 2018 Sep 12]. Available from: http://www .cdc.gov/diabetes/pubs/pdf/kidney_factsheet.pdf

20. Orantes CM, Herrera R, Almaguer M, Brizuela EG, Núñez L, Alvarado NP, et al. Epidemiology of chronic kidney disease in adults of Salvadoran agricultural communities. MEDICC Rev. 2014 Apr;16(2):23-30.

21. Herrera R, Orantes $C M$, Almaguer $M$, Alfonso $P$, Bayarre HD, Leiva IM, et al. Clinical characteristics of Chronic Kidney Disease of Nontraditional Causes in Salvadoran Farming Communities. MEDICC Rev. 2014 Apr;16(2):39-48.

22. López-Marín L, Chávez Y, García XA, Flores WM, García YM, Herrera R, et al. Histopathology of chronic kidney disease of unknown etiology in Salvadoran agricultural communities. MEDICC Rev. 2014 Apr;16(2):49-54.

23. Orantes CM, Herrera R, Almaguer M, Brizuela EG, Alvarado NP, Fuentes JE, et al. Chronic kidney disease in children and adolescents in Salvadoran farming communities: Nefrosalva Pediatric Study (2009-2011). MEDICC Rev. 2016 JanApr;18(1-2):23-30.

24. CHMCA. San Salvador Declaration: comprehensive management of chronic tubulinterstitial kidney disease of Central America (CTKDC) predominantly affecting agricultural communities. Council of Health Ministers of Central America. MEDICC Rev [Internet]. 2014 Apr [cited 2018 Sep 12];16(2). Available from: http://www.me dicc.org/medic-creview/documents/San_Sal vador_English_online.pdf

25. COMISCA. Resolución de la XXXV Reunión del Consejo de Ministros de Salud de Centro América y República Dominicana [Internet]. San Salvador: COMISCA; 2011 [cited 2018 Sep 12]. Available from: http://www.sica.int/busqueda/ busqueda_basica.aspx?ldMod=3. Spanish.

26. Pan American Health Organization. 52nd Directing Council. Resolution CD52.R10. Chronic kidney disease in agricultural communities in Central America [Internet]. Washington, D.C.: Pan American Health Organization; 2013 Oct [cited 2018 Sep 12]. Available from: http://www .paho.org/hq/index.php?option=com_content\& view $=$ article\&id $=8833 \&$ ltemid $=40033 \&$ lang $=e n$

27. Orduñez P, Sáenz C, Martínez R, Chapman E, Reveiz L, Becerra F. The Epidemic of Chronic Kidney Disease in Central America. Lancet Glob Health. 2014 Aug;2(8):e440-1.

28. Ministry of Health of El Salvador; National Institute of Health of El Salvador. Encuesta nacional de enfermedades crónicas no transmisibles en población adulta de El Salvador ENECAELS. Resultados relevantes [Internet]. San Salvador, El Salvador: Ministry of Health of El Salvador; National Institute of Health of El Salvador; 2015 [cited 2018 Sep 12] 36 p. Available from: http://www.salud.gob.sv/archi vos/comunicaciones/archivos_comunicados2017/ pdf/presentaciones_evento20032017/01-ENECA -ELS-2015.pdf. Spanish.
29. World Health Organization. El Manual de vigilancia STEPS de la OMS: el método STEPwise de la OMS para la vigilancia de los factores de riesgo de las enfermedades crónicas. Geneva: World Health Organization; 2006. Spanish.

30. Coresh J, Astor BC, Greene T, Eknoyan G, Levey AS. Prevalence of chronic kidney disease and decreased kidney function in the adult US population: Third National Health and Nutrition Examination Survey. Am J Kidney Dis. 2003 Jan;41(1):1-12.

31. Django Software Foundation [Internet]. [place unknown]: Django Software Foundation; c20052019. Django Documentation Release 1.5.3; 2013 Sep 10 [cited 2018 Sep 12]. Available from: https://docs.djangoproject.com/en/1.5/

32. World Health Organization. Operational Guidelines for Ethics Committees that review Biomedical Research. Geneva: World Health Organization; 2000. $32 \mathrm{p}$

33. Stevens LA, Claybon MA, Schmid CH, Chen J, Horio M, Imai E, et al. Evaluation of the Chronic Kidney Disease Epidemiology Collaboration equation for estimating the glomerular filtration rate in multiple ethnicities. Kidney Int. 2011 Mar;79(5):555-62.

34. Kidney Disease Improving Global Outcomes (KDIGO). 2012 clinical practice guideline for the evaluation and management of chronic kidney disease. International Society of Nephrology. Kidney Int Suppl [Internet]. 2013 [cited 2018 Sep 12];3(1):1-150. Available from: https://www .sciencedirect.com/journal/kidney-international -supplements/vol/3/issue/1

35. Epidat: programa para análisis epidemiolóxico de datos. Versión 4.2, xullo 2016. Galicia: Consellería de Sanidade, Xunta de Galicia; Pan American Health Organization; World Health Organization; Universidade CES, Colombia; 2016 Jul. Spanish

36. Kalton G, Flores I. Weighting methods. J Off Statistics. 2003;19(2):81-97.

37. Lundström S, Särndal CE. Calibration as a standard method for the treatment of nonresponse. $J$ Off Statistics. 1999;15(2):305-27.

38. Brück K, Jager KJ, Dounousi E, Kainz A, Nitsch $\mathrm{D}$, Ärnlöv $\mathrm{J}$, et al. Methodology used in studies reporting chronic kidney disease prevalence: a systematic literature review. Nephrol Dial Transplant. 2015 Aug;30 Suppl 4:iv6-iv16.

39. National Kidney Foundation. K/DOQI Clinical Practice Guidelines for Chronic Kidney Disease: Evaluation, Classification, and Stratification. Am J Kidney Dis. 2002 Feb;39 (2 Suppl 1):S1-266.

40. Orantes Navarro CM, Herrera Valdés R, Almaguer López M, Calero DJ, Fuentes de Morales $\mathrm{J}$, Alvarado Ascencio NP, et al. Epidemiological characteristic of chronic kidney disease of nontraditional causes in women of agricultural communities of El Salvador. Clin Nephrol. 2015;83(7 Suppl 1):S24-31.

41. Raines N, González M, Wyatt C, Kurzrok M, Pool $\mathrm{C}$, Lemma T, et al. Risk factors for reduced glomerular filtration rate in a Nicaraguan community affected by Mesoamerican nephropathy. MEDICC Rev. 2014 Apr;16(2):16-22.

42. Gifford FJ, Gifford RM, Eddleston M , Dhaun N. Endemic nephropathy around the world. Kidney Int Rep. 2017 Mar;2(2):282-92

43. Centers for Disease Control and Prevention (CDC). Prevalence of chronic kidney disease and associated risk factors-United States, 19992004. Morb Mortal Wkly Rep [Internet]. 2007 Mar 2 [cited 2018 Sep 12];56(8):161-5. Available from: https://www.cdc.gov/mmwr/preview/ mmwrhtml/mm5608a2.htm

44. Centers for Disease Control and Prevention (CDC). Age-adjusted prevalence of CKD Stages 1-4 by Gender 1999-2012. Chronic Kidney Dis- ease (CKD) Surveillance Project [Internet]. Atlanta: Centers for Disease Control and Prevention (CDC); 2016 [cited 2019 Feb 12] Available from: https://nccd.cdc.gov

45. Takahashi S, Okada K, Yanai M. The Kidney Early Evaluation Program (KEEP) of Japan: results from the initial screening period. Kidney Int Suppl [Internet]. 2010 Mar [cited 2018 Sep12];77(116 Suppl):S17-23. Available from: https://www.kidney-international.org/article/ S0085-2538(15)54182-3/fulltext

46. Mathew TH, Corso O, Ludlow M, Boyle A, Cass A, Chadban SJ, et al. Screening for chronic kidney disease in Australia: a pilot study in the community and workplace. Kidney Int Suppl. 2010 Mar;77(116 Suppl):S9-16.

47. Otero A, de Francisco AL, Gayoso P, García F; EPIRCE Study Group. Prevalence of chronic renal disease in Spain: Results of the EPIRCE study. Nefrologia [Internet]. 2010 [cited 2018 Sep 12];30(1):78-86. Spanish, English. Available from: http://dialnet.unirioja.es/servlet/ articulo? codigo $=3361355$

48. Hallan SI, Coresh J, Astor BC, Äsberg A, Powe $\mathrm{NR}$, Romundstad $\mathrm{S}$, et al. International comparison of the relationship of chronic kidney disease prevalence and ESRD risk. J Am Soc Nephrol [Internet]. 2006 Aug [cited 2018 Sep 12];17(8):2275-84. Available from: http://jasn .asnjournals.org/content/17/8/2275.long

49. Zhang QL, Rothenbacher D. Prevalence of chronic kidney disease in population-based studies: systematic review. BMC Pub Health. 2008 Apr 11;8:117.

50. Cerón A, Fort MP, Morine CM, Lou-Meda R. Chronic kidney disease among children in Guatemala. Rev Panam Salud Pública. 2014;36(6):376-82.

51. Valcke M, Orantes CM, Lavasseur ME. Chronic disease of undetermined etiology and pesticide exposure: an update on recent data. Presentation at the Second International Research Workshop on Mesoamerican Nephropathy, Consortium on the Epidemic of Nephropathy in Central America and México (CENCAM) and Central American Program on Work, Environment and Health (SALTRA); 2015 Nov 18-20; San José, Costa Rica. San Juan de Costa Rica: SALTRA; 2015.

52. Sanoff SL, Callejas L, Alonso CD, Hu Y, Colindres $\mathrm{RE}$, Chin $\mathrm{H}$, et al. Positive association of renal insufficiency with agriculture employment and unregulated alcohol consumption in Nicaragua. Ren Fail. 2010;32(7):766-77.

53. O'Donnell JK, Tobey M, Weiner DE, Stevens LA, Johnson S, Stringham P, et al. Prevalence of and risk factors for chronic kidney disease in rural Nicaragua. Nephrol Dial Transplant. 2011 Sep;26(9):2798-805.

54. Torres C, Aragón A, González M, López I, Jakobsson K, Elinder CG, et al. Decreased kidney function of unknown cause in Nicaragua: a community-based survey. Am J Kidney Dis. 2010 Mar:55(3):485-96.

55. Payán-Rentería R, Garibay-Chávez G, RangelAscencio R, Preciado-Martínez V, Muñoz-Islas L, Beltrán-Miranda C, et al. Effect of chronic pesticide exposure in farm workers of a Mexico community. Arch Environ Occup Health. 2012;67(1):22-30.

56. Ruiz-Suárez LE, Castro-Chan RA, Rivero-Pérez NE. Levels of organochlorine pesticides in blood plasma from residents of malaria-endemic communities in Chiapas, Mexico. Int J Environ Res Public Health. 2014 Oct;11(10):44-60.

57. Lebov JF, Engel S, Richardson D, Hogan SL, Hoppin JA, Sandler DP. Pesticide use and risk of end-stage renal disease among licensed pesticide applicators in the Agricultural Health Study. Occup \& Environm Med. 2016 Jan;73(1):3-12. 
58. Hsu CY, Iribarren C, McCulloch CE, Darbinian J, Go AS. Risk factors for end-stage renal disease: 25-year follow-up. Arch Intern Med. 2009 Feb 23;169(4):342-50.

59. Jayasumana C, Gunatilake S, Senanayake P. Glyphosate, hard water and nephrotoxic Metals: are they the culprits behind the epidemic of chronic kidney disease of unknown etiology in Sri Lanka? Int J Environ Res Public Health. 2014 Feb 20;11(2):2125-47.

60. Jayasumana C, Paranagama P, Agampodi S, Wijewardane C, Gunatilake S, Siribaddana S. Drinking well water and occupational exposure to herbicides is associated with chronic kidney disease, in Padavi Sripura, Sri Lanka. Environ Health. 2015 Jan 18;14:6.

61. Bravo V, Rodríguez T, Van Wendel de Joode B, Canto N, Calderón GR, Turcios M, et al. Monitoring pesticide use and associated health hazards in Central America. Int J Occup Environ Health. 2011Jul-Sep;17(3):258-69.

62. Weaver VM, Fadrowski JJ, Jaar BG. Global dimensions of chronic kidney disease of unknown etiology (CKDu): a modern era environmental and/or occupational nephropathy? BMC Nephrol. 2015 Aug 19;16:145

63. Chandrajith R, Nanayakkara S, Itai K, Aturaliya $\mathrm{TN}$, Dissanayake CB, Abeysekera $\mathrm{T}$, et al. Chronic kidney diseases of uncertain etiology (CKDue) in Sri Lanka: geographical distribution and environmental implications. Environ Geochem Health. 2011 Jun;33(3):267-78.

64. Elledge MF, Redmon JH, Levine KE, Levine KE, Wickremasinghe RJ, Wanigasariya $\mathrm{KP}$, et al. Chronic kidney disease of unknown etiology in Sri Lanka: quest for understanding and global implications. Research Brief North Carolina: RTI Press [Internet]. 2014 May [cited 2018 Sep 12]; [about 4 pages]. Available from: https://www.rti .org/sites/default/files/resources/rti-publication -file-fb1d2db7-bd51-4f85-a8d1-3e38ba9c4da7.pdf

65. Inter Press Service [Internet]. Rome: Inter Press Service; c2019. Health. Study links kidney disease in Sri Lanka's farm belt to agrochemicals; 2012 [cited 2018 Sep 12]; [about 3 screens]. Available from: http://www.ipsnews.net/2012/08/ study-links-kidney-disease-in-sri-lankas-farm -belt-to-agrochemicals/

66. Jayatilake N, Mendis S, Maheepala P, Mehta FR; CKDu National Research Project Team. Chronic kidney disease of uncertain aetiology: prevalence and causative factors in a developing country. BMC Nephrol. 2013 Aug 27:14:180.
67. Rajapurkar MM, John GT, Kirpalani AL, Abraham G, Agarwal SK, Almeida AF, et al. What do we know about chronic kidney disease in India: first report of the Indian CKD registry. BMC Nephrol. 2012 Mar 6;13:10.

68. Singh AK, Farag YM, Mittal BV, Subramanian KK, Reddy SR, Acharya VN, et al. Epidemiology and risk factors of chronic kidney disease in India - results from the SEEK (Screening and Early Evaluation of Kidney Disease) study. BMC Nephrol. 2013 May 28;14:114.

69. El Minshawy O, Ghabrah T, El Bassuoni E. Endstage renal disease in Tabuk Area, Saudi Arabia: an epidemiological study. Saudi J Kidney Dis Transpl. 2014 Jan;25(1):192-5

70. Barsoum RS. Burden of chronic kidney disease: North Africa. Kidney Int Suppl (2011). 2013 May;3(2):164-6.

71. Seck SM, Doupa D, Gueye L, Dia CA. Prevalence of chronic kidney disease and associated factors in Senegalese populations: a communitybased study in Saint-Louis. Nephrourol Mon. 2014 Sep 5:6(5):e19085.

72. Jayasumana $C$, Orantes $C$, Herrera R, Almaguer M, López L, Silva LC, et al. Chronic interstitial nephritis in agricultural communities: a worldwide epidemic with social, occupational and environmental determinants. Nephrol Dial Transplant. 2017 Feb 1;32(2):234-41.

73. Wijkström J. Chronic kidney disease of unknown etiology in Central America and Sri Lanka: renal morphology and clinical characteristics [dissertation]. [Stockholm]: Karolinska University Department of Clinical Science, Intervention and Technology; 2017 [cited 2018 Sep 12]. 63 p. Available from: https://openarchive.ki.se/xmlui/ bitstream/handle/10616/46000/Thesis_Julia_Wi jkstrom. pdf?sequence=1

74. Bandarage A. Political economy of epidemic kidney disease in Sri Lanka. SAGE Open. 2013 Oct-Dec;3(4):1-13.

75. Reveiz L, Pinzón-Flórez C, Glujovsky D, Elias V, Orduñez P. Establecimiento de prioridades de investigación en la enfermedad renal crónica de causas no tradicionales en Centroamérica. Rev Panam Salud Pública. 2018 Mar;42:13. Spanish.

\section{THE AUTHORS}

Carlos Manuel Orantes-Navarro, nephrologist, research coordinator of the National Institute of Health, Ministry of Health of El Salvador (INS/MINSAL), San Salvador, El Salvador.
Miguel M. Almaguer-López, nephrologist with a master's degree in epidemiology. Senior researcher, consulting professor, and chair, Department of Preventive Nephrology, Nephrology Institute (INEF), Havana, Cuba, and consultant to PAHO.

Patricia Alonso-Galbán, physician with dual specialties in biostatistics and family medicine with a master's degree in biostatistics. Associate researcher and assistant professor. National Medical Sciences Information Center, Havana, Cuba.

Moisés Diaz-Amaya, mathematician and statistician in the Research Unit, INS/MINSAL, San Salvador, El Salvador.

Samuel Hernández, mathematician and statistician in the Research Unit, INS/MINSAL, San Salvador, El Salvador.

Raúl Herrera-Valdés, nephrologist, with a doctorate in medical sciences and advanced doctorate in science. Senior researcher and consulting professor, INEF, Havana, Cuba. Head of the National Nephrology Group, Ministry of Public Health, Cuba and consultant to PAHO.

Luis Carlos Silva-Aycaguer (Corresponding author: Icsilva@infomed.sld.cu), mathematician with a doctorate in mathematics and advanced doctorate in science. Distinguished researcher and consulting professor, National School of Public Health, Havana, Cuba.

Submitted: October 15, 2018

Approved for publication: May 10, 2019 Disclosures: None

\section{3rd Iberoamerican Pharmacometrics Network Congress}

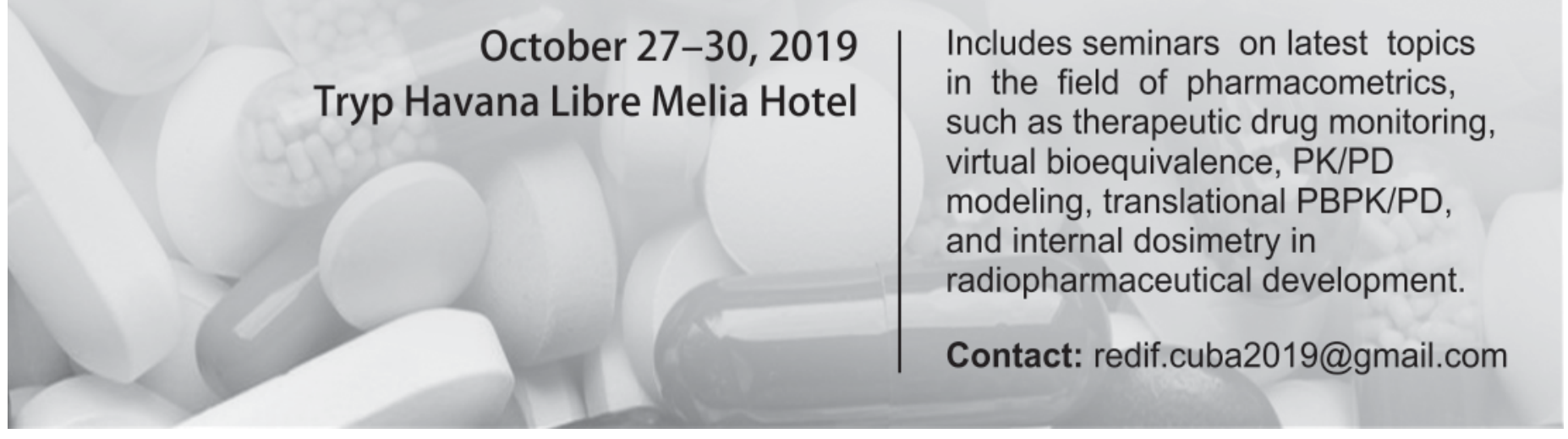

